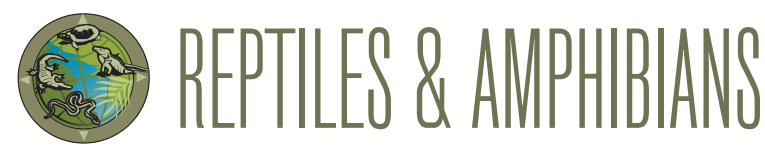

\title{
Notes on the Natural History and Distribution of Uribe's Cat-eyed Snake, Leptodeira uribei (Dipsadidae)
}

Luis Francisco Nieto-Toscano and Matías Martínez-Coronel

Departamento de Biología, Universidad Autónoma Metropolitana-Iztapalapa, Ciudad de México, México (luisnietotoscano913@gmail.com)

U ribe's Cat-eyed Snake (Leptodeira uribei) is a Mexican endemic that ranges throughout the Pacific Coastal Plain from Jalisco to Oaxaca (Mata-Silva et al. 2017). These snakes are nocturnally active inhabitants of lowland tropical deciduous forest and are most active during the rainy season (Reyes-Velasco and Mulcahy 2010). Little is known about this species in nature. Streicher et al. (2011) found a female with six eggs in July, and Torres-Pérez-Coeto et al. (2018) recorded a Mexican Shovel-headed Treefrog (Triprion spatulatus) in its diet. Herein we provide a new distribution record, new dietary items, and reproductive data for the species.

We encountered two L. uribei at Rancho "El Santo," Santiago Pinotepa Nacional, Oaxaca, Mexico. At 1400 h on 3 June 2019, we found the corpse of an adult female (total length $610 \mathrm{~mm}$; tail length $122 \mathrm{~mm}$; Fig. 1) on a trail in tropical deciduous forest $\left(16.3680^{\circ} \mathrm{N}, 98.1861^{\circ} \mathrm{W}\right.$; WSG 84; 198 $\mathrm{m}$ asl). Local people had killed the snake when they found it inside a hollow trunk. We also found a subadult (total length $395 \mathrm{~mm}$; tail length $95 \mathrm{~mm}$; Fig. 2A) on leaf litter in tropical

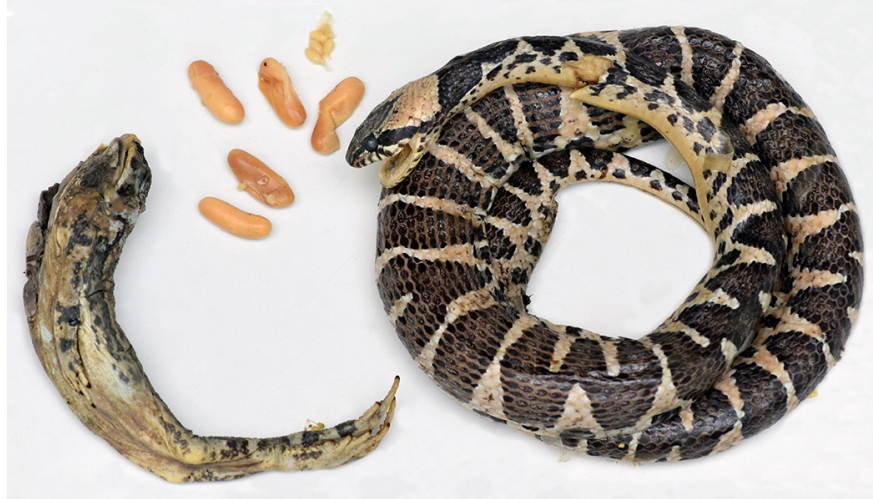

Fig. 1. A gravid female Uribe's Cat-eyed Snake (Leptodeira uribei) from Rancho "El Santo," Santiago Pinotepa Nacional, Oaxaca, Mexico, with five well-developed oviductal eggs and a prey item identified as a Marbled Toad (Incilius marmoreus). Photograph by Luis Francisco Nieto-Toscano.
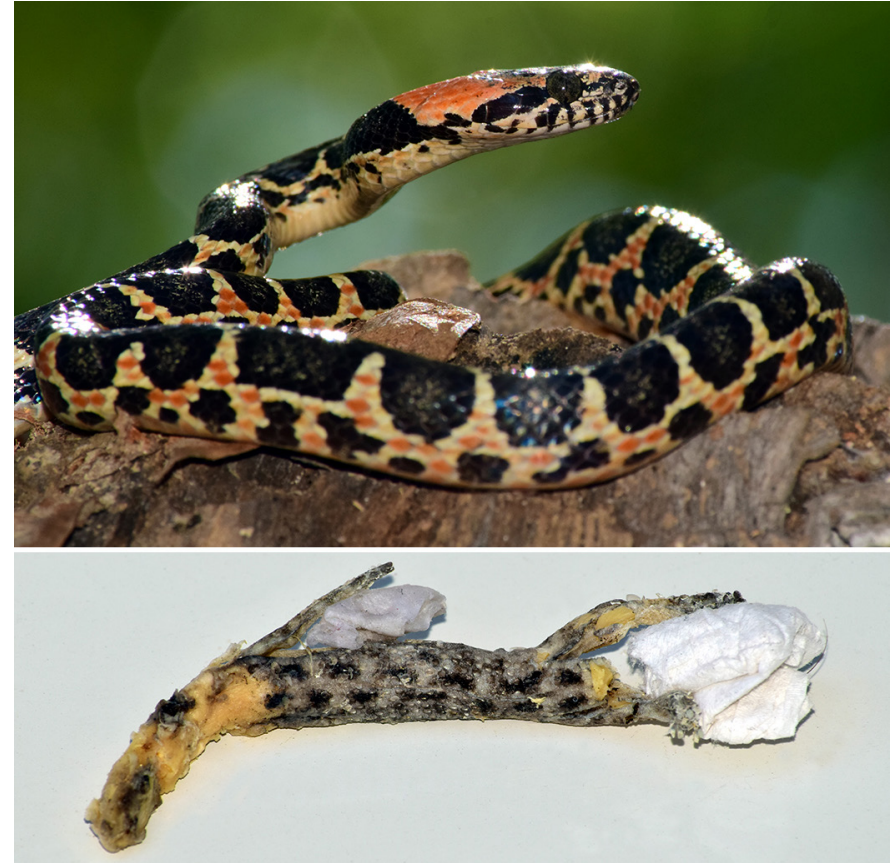

Fig. 2. A subadult Uribe's Cat-eyed Snake (Leptodeira uribei) encountered in lowland tropical deciduous forest at Rancho "El Santo," Santiago Pinotepa Nacional, Oaxaca, Mexico, and a Yellow-bellied Gecko (Phyllodactylus tuberculosus) it regurgitated. Photographs by Luis Francisco Nieto-Toscano.

deciduous forest $\left(16.3605^{\circ} \mathrm{N}, 98.1755^{\circ} \mathrm{W}\right.$; WSG 84; $185 \mathrm{~m}$ asl) at $1000 \mathrm{~h}$ on 20 December 2020. After measuring the snake, we released it at the same location. These two individuals represent a new municipal distribution record, fill a gap between the closest localities, Rio Grande, Municipality of Villa de Tututepec de Melchor Ocampo, Oaxaca (MataSilva et al. 2017), and San Andrés de la Cruz, Municipality of Atoyac de Álvarez, Guerrero (Vázquez-Arroyo et al. 2019), and reinforce the contention of a continuous distribution from Jalisco to southern Oaxaca. 
The adult female contained five well-developed oviductal eggs that measured $16 \times 6 \mathrm{~mm}, 16 \times 5 \mathrm{~mm}$, and $15 \times 4$ $\mathrm{mm}$ and its stomach contained a Marbled Toad (Incilius marmoreus, total length $67 \mathrm{~mm}$; Fig. 1). When handled, the subadult regurgitated a partially digested Yellow-bellied Gecko (Phyllodactylus tuberculosus, Fig. 2). This is the first time that $I$. marmoreus and $P$. tuberculosus have been recorded in the diet of $L$. uribei. Both prey species are nocturnally active and presumably were captured at night when the snake was foraging.

The specimens described herein have been deposited in the Collection of Amphibians and Reptiles of the Metropolitan Autonomous University-Iztapalapa: I. marmoreus (CAR-I 1505), P. tuberculosus (CAR-I 1506), and adult L. uribei (CAR-I 1507). The identity of the snakes was confirmed by Aurelio Ramírez-Bautista.

\section{Acknowledgements}

We thank Angel Toscano and Aurelio López for support with the fieldwork.

\section{Literature Cited}

Mata-Silva, V., E. García-Padilla, D.L. DeSantis, A. Rocha, L.D. Wilson, and A. Ramírez-Bautista. 2017. Distribution notes: Leptodeira uribei (RamírezBautista and Smith, 1992). Mesoamerican Herpetology 4: 472-473.

Reyes-Velasco, J. and D.G. Mulcahy. 2010. Additional taxonomic remarks on the genus Pseudoleptodeira (Serpentes: Colubridae) and the phylogenetic placement of "P. uribei." Herpetologica 66: 99-110. https://doi.org./10.1655/09-019.1.

Streicher, J.W., C.L. Cox, C.M. Sheehy III, M.J. Ingrasci, and R.U. Tovar. 2011. Pseudoleptodeira uribei (Uribe's False Cat-eyed Snake). Reproduction. Herpetological Review 42:101.

Torres-Pérez-Coeto, J., J. Alvarado-Díaz, and I. Suazo-Ortuño. 2018. Leptodeira uribei. (Bautista and Smith, 1992). Diet. Mesoamerican Herpetology 5: 167-169.

Vázquez-Arroyo, E., R. Palacios-Aguilar, C. Pino-Ocampo, and R. Santos-Bibiano. 2019. Geographic distribution: Leptodeira uribei (Uribe's False Cat-Eyed Snake). Herpetological Review 50: 331. 